Brit. J. industr. Med., 1956, 13, 251.

\title{
PNEUMOCONIOSIS OF KAOLIN WORKERS
}

\author{
BY \\ L. W. HALE, J. GOUGH, E. J. KING, and G. NAGELSCHMIDT \\ From the West Cornwall Hospitals Group, Welsh National School of Medicine, Cardiff, the Postgraduate Medical \\ School, London, and the Safety in Mines Research Establishment, Sheffield
}

(RECEIVED FOR PUBLICATION DECEMBER 15, 1955)

Kaolin, or china clay, is an important raw material which is exploited industrially in Cornwall, England, in Georgia, U.S.A., and in several other localities. In the past it has been assumed that exposure to kaolin dust does not lead to disabling pneumoconiosis, but over the past 10 years the experience of one of us in Cornwall has suggested that this may be incorrect. Difficulty has always been experienced, however, in obtaining an occupational history uncomplicated by periods in other work carrying a silicosis risk, such as metal mining, granite dressing, or the like.

In this communication, clinical and radiological observations of several cases will be described. Three of these men had worked at the same place in Cornwall, and had been engaged in drying and bagging disintegrated china clay. One of them came to necropsy in 1950, and the pathological findings and analyses of the mineral contents of the lung are given. Similar data are also given for a kaolin worker from Georgia, U.S.A.

\section{Working Conditions}

Winning of china clay in Cornwall is generally carried out wet, and there is very little dust produced until the refined clay is dried and shipped. Until about 1920, the clay was dried in open sheds to a moisture content of 15 to $20 \%$, and although some steam and dust were produced in these sheds, dust concentrations were not very high. Since that time, however, there has been a tendency to produce drier clay by the technique of filter pressing. Under these conditions much higher dust concentrations exist, especially in the drying plants where fine clays are disintegrated after drying and filled into bags. Three of the men described in the following case histories had worked in a plant of this type for over 20 years. Very high dust concentrations are also found in the holds of ships loading china clay.

Clinical, Radiological, and Pathological Observations Case 1.-A man (C. P.) aged 44 years was first seen on March 15, 1949, complaining of shortness of breath, at rest as well as on activity, for four years past; some tight feeling across both pectoral regions; cough, especially at night, with thick white sputum (reputed to be as much as a teacupful per 24 hours), never bloody. He had lost weight from $182 \mathrm{lb}$. to $157 \mathrm{lb}$. and he noted some weakness and tiredness. There was no relevant past history of illness and no family history of respiratory disease.

He left school at 14 years. He was a kettle-boy in clay works, doing odd jobs for two years, and for the past 28 years has worked at a kaolin mill, bagging the finest pharmaceutical grade of kaolin powder.

On examination he was in poor general condition; he was dark skinned, slightly cyanosed, showed no finger clubbing, and was easily dyspnoeic on slight exertion.

The chest expansion was only $1 \frac{1}{4}$ in. by measurement. The signs were those of emphysema, but no rales. There was no hypertension and no clinical evidence of cardiac disease. Examination in other respects was negative. His haemoglobin was $108 \%$ and the white cell count was normal. The E.S.R. was $19 \mathrm{~mm}$. in one hour. Sputum was requested but was not obtained.

His radiograph at that time showed well-marked nodulation of silicotic type, with coalescence of the nodules in several areas. Emphysema was present.

He was seen again in April and June of 1949, and no new physical signs were noted, though his respiratory disability had increased, and the dyspnoea had become distressing. He stated that three of his mates working in the same proces $;$ had died, at ages about 55, 50, and 31, " all of them went short of breath".

Enquiry about the workmates mentioned above did not reveal any conclusive evidence that they had had pneumoconiosis; they had been considered to have bronchitis or asthma but no radiological or pathological evidence was obtainable.

When seen in March, 1950, his weight had fallen to $144 \mathrm{lb}$. and his dyspnoea was very distressing. He had been in bed most of the preceding four months.

His general condition was much poorer but he was not markedly toxaemic. His respirations were 44 per minute. Chest movement was very small, there was no gross dullness anywhere, the breath sounds were harsh over the front of the thorax, and broncho-cavernous over both upper zones there. No moist sounds were heard anywhere. His sputum specimens were spoiled in transit. 


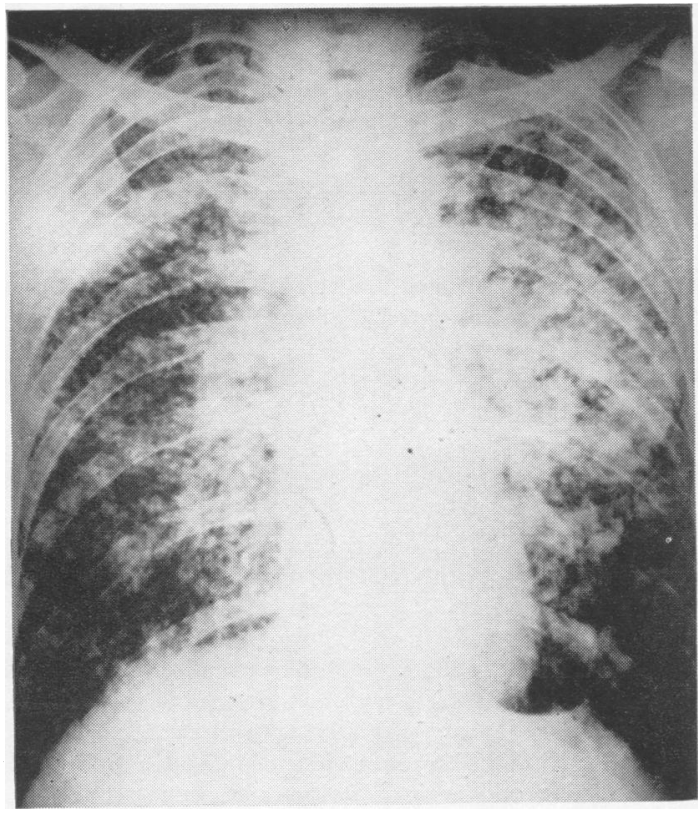

FIG. 1.-Radiograph of Case 1 (C. P.).

The E.S.R. had risen to $36 \mathrm{~mm}$. in one hour. There had been a change in the radiological appearances, multiple areas of coalescent shadowing being present throughout the greater part of both lung fields (Fig. 1). In the left apex there was a rounded translucent area suggestive of cavitation. A diagnosis of silico-tuberculosis was made.

He died on April 19, 1950, and a necropsy was performed. There was obvious emphysema when the thorax was opened. Both lungs were densely adherent, in the upper portions especially. The pleura showed the appearances characteristic of silicosis. The hilar glands were dark, hard, and fibrosed.

Large thin sections of the left lung showed grey nodules, most of which were about 1 to $4 \mathrm{~mm}$. in diameter, but some up to $6 \mathrm{~mm}$. Some of these were discrete but many were confluent. They were present in greatest numbers in the upper three-quarters of the lung and only the lingula was free of nodules. The grey colour of the lesions was unlike that seen in any other form of pneumoconiosis. There were areas of caseation throughout the lung with cavity formation several centimetres across at the apex and several cavities of about $1 \mathrm{~cm}$. across in the lower part of the upper lobe and in the lower lobe. In the lower half of the lower lobe the tuberculosis had an acinose formation with grey nodules in the centres and paler areas of caseation around these centres.

The right lung showed great thickening of the pleura. The hilar glands were enlarged, grey, and caseous. There were nodules up to $6 \mathrm{~mm}$. in diameter throughout the lung, except in the lower half of the middle lobe. These were grey and circumscribed, most were discrete, some were confluent.

There was extensive caseous tuberulosis throughout the lung with acinose formation in some parts.

Histology.-Most of the nodular lesions showed caseous tuberculosis, but some nodules had hyaline fibrosis which may have antedated the tuberculosis and been produced by the dust. In many respects they simulated classical silicotic lesions. In the many histological sections taken there were very few dust foci unaffected by tuberculosis, but from the occasional ones seen it would appear that the dust had been causing hyaline fibrosis (Fig. 2). Against this view is the fact that in places in the hilar glands where there was a great deal of dust there was little fibrosis. There was one hyaline fibrous nodule in a lymph node, but this is not an uncommon finding where inert dust is present in a gland, and was presumably a focus of healed tuberculosis.

The analysis of the lung dust of Case 1 is given later.

Case 2.-A man (W. K.) aged 67 complained of productive cough for " several years", with a moderate quantity of yellowish sputum, never bloody. He complained of shortness of breath recently, but no pain. When seen in 1952 he was rather thin; of average appearance for his age, not toxaemic, and with no finger clubbing. The physical signs were those of well-marked emphysema, with a few moist sounds at the right base. Examination of the cardiovascular and other systems was negative.

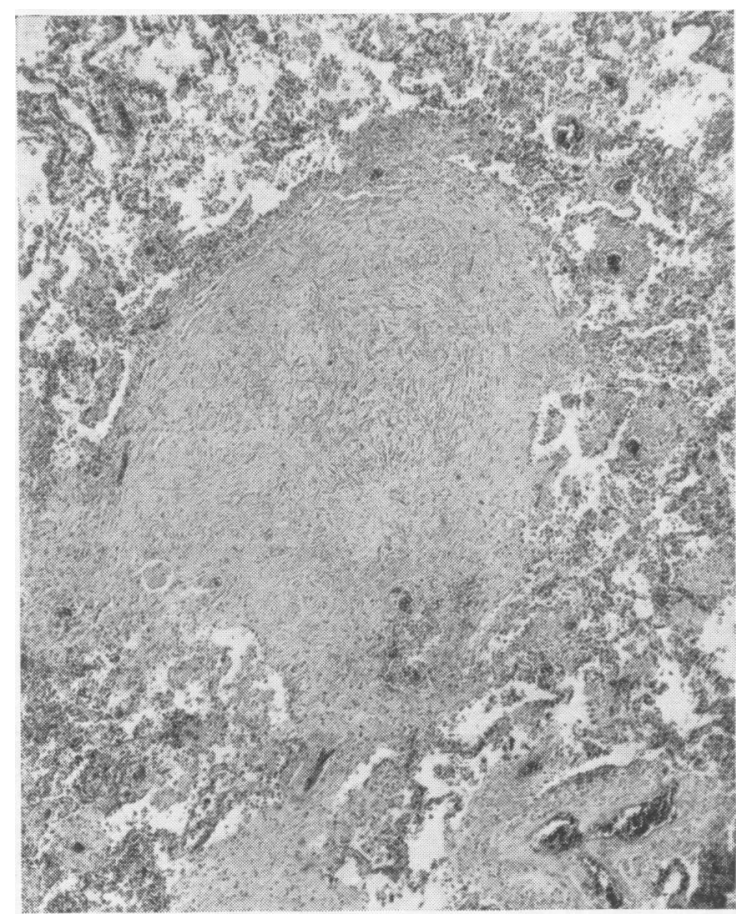

FIG. 2.-Nodule of fibrosis in Case 1 (C. P.) $\times 55$. 


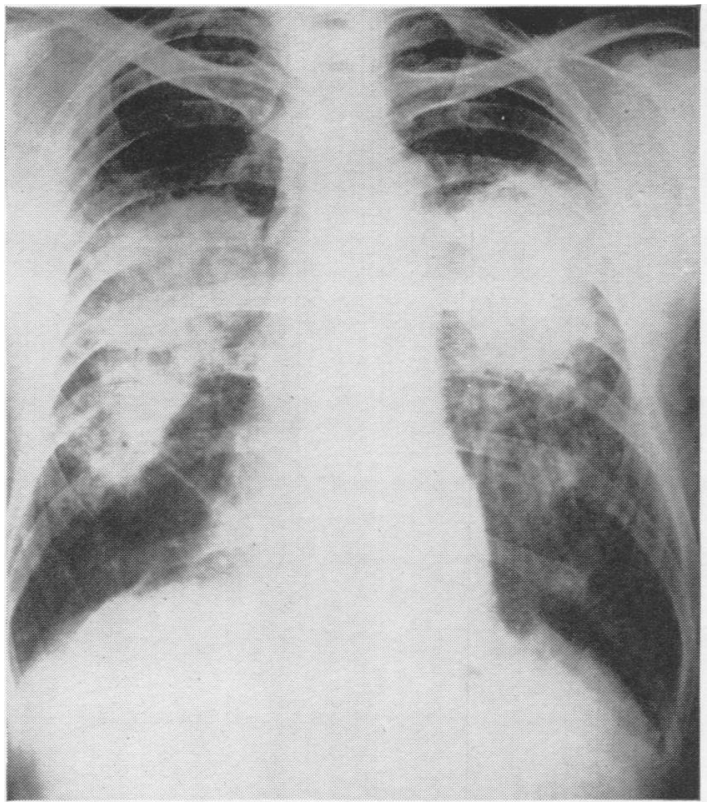

FIG. 3.-Radiograph of Case 2 (W. K.).

There was no relevant past history of illness, and no family history of respiratory disease.

He had spent practically all his working life in the china-clay industry; he had never worked underground, nor with granite or china stone, and for about 30 years past had bagged finely divided kaolin in the mills.

His radiograph (Fig. 3)* showed a low diaphragm and considerable emphysema. In addition, large areas of massive fibrosis were seen on both sites, involving the apical segments of both lower lobes; these were well defined and discrete in outline, and exactly resembled the radiological appearances seen in the progressive massive fibrosis of coal-miners. In addition there was an increased linear striation throughout both lung fields. Tomographs showed no evidence of cavitation. The sputum was repeatedly negative for tubercle bacilli.

The corrected vital capacity was $1,833 \mathrm{ml}$. Bronchoscopy showed no evidence of neoplasm and this conclusion has been supported by his subsequent progress. He has become increasingly disabled by shortness of breath; in March, 1955, he was unable to do any work. His disability was certified as $100 \%$ by the Pneumoconiosis Medical Board.

Case 3.-A man (E. T.) aged 44 was referred in March, 1953, on account of shortness of breath and a tight feeling in the chest in the mornings for some years past. He had been regarded as a case of bronchial asthma.

* We have recently discovered another case, with quite similar radiological appearances, but not considered to have been under observation long enough for inclusion at this date.

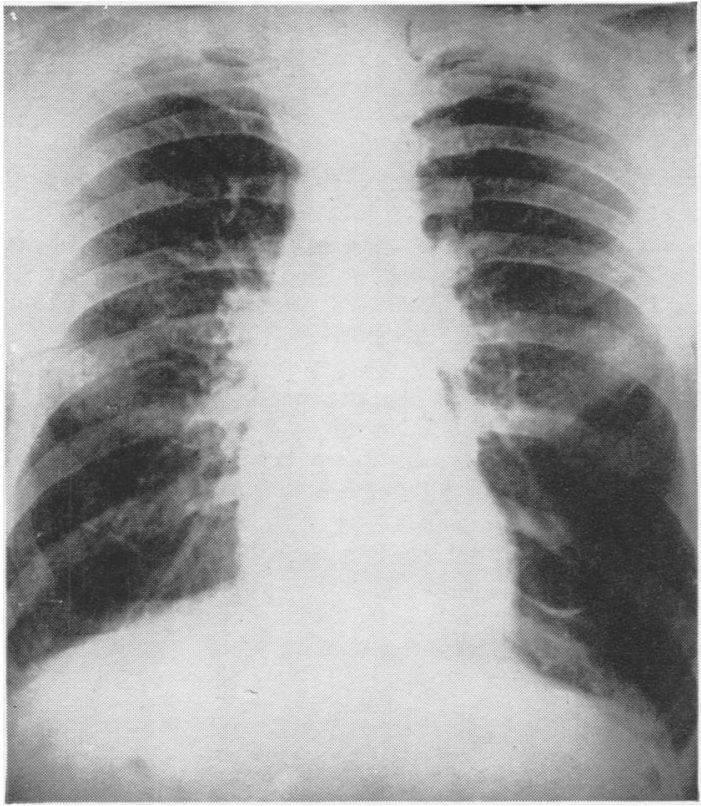

Fig. 4.-Radiograph of Case 3 (E. T.).

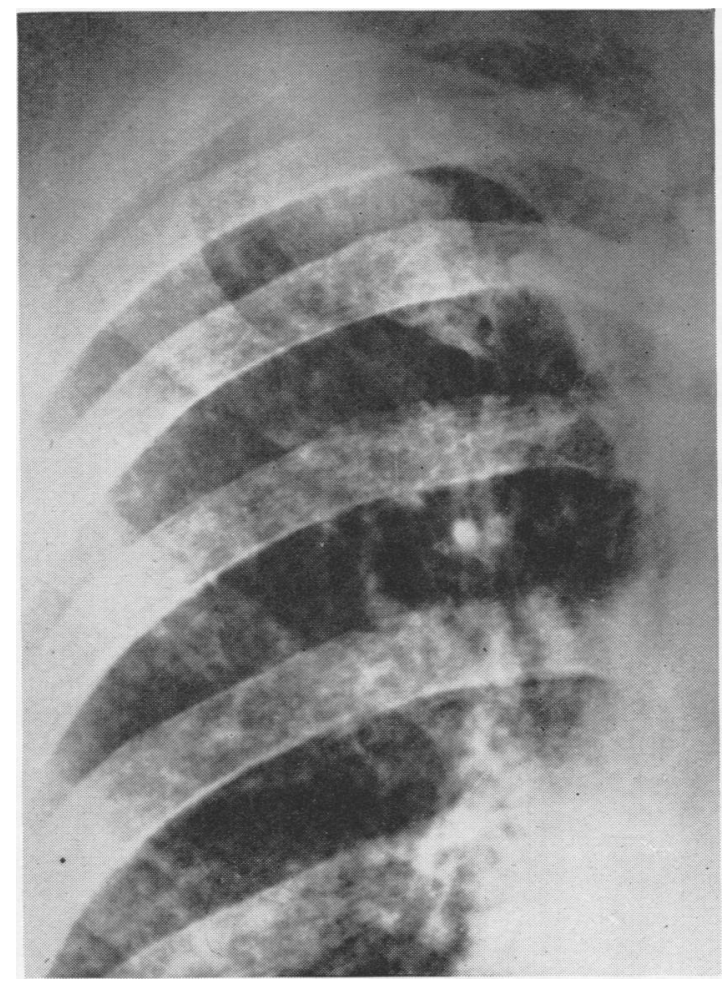

FIG. 4a.-Detail of right upper zone in Case 3 (E. T.). 
He had left school at 14 years and worked in the china-clay industry all his life, as a tip-boy for one year, as a general labourer in the pits for five years, and in the same mill as C. P. and W. K. for 24 years, mostly bagging fine milled kaolin powder. He had joined the Army in the recent war, but was invalided out after two months " on account of his chest".

He stated that he was only just able to do his job, but had not had any long absence from work. There was no history of other significant past illness. He was a man in fairly good general condition, slightly cyanosed, with a chest held in the inspiratory position, poor air entry, and physical signs of marked bronchospasm.

The radiograph (Fig. 4) showed diffuse nodular mottling typical of pneumoconiosis, with considerable accentuation of the bronchovascular markings. There was no evidence of focal secondary infection.

He has remained under periodic out-patient observation ever since, and shows no general deterioration. There is much variation in the degree of bronchospasm. His disability has been assessed at $30 \%$ by the Pneumoconiosis Medical Panel. He is now occupied in the same works at a light job carrying no dust risk.

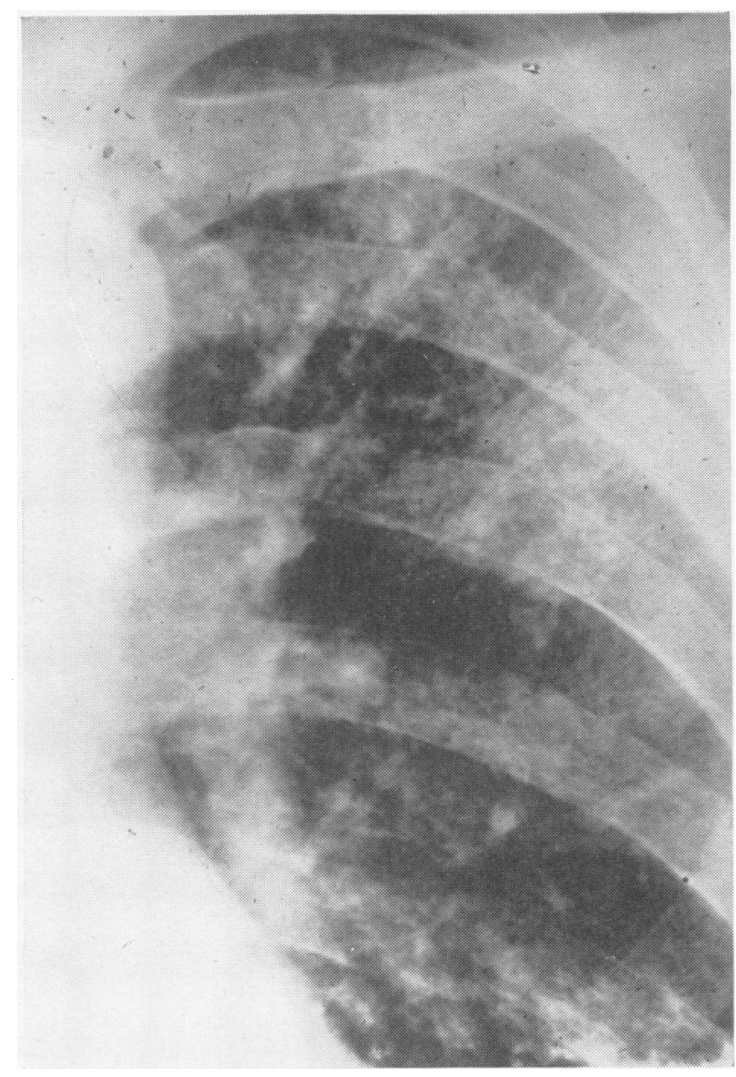

FIG. 5.-Detail of left upper zone in Case 4 (N. C.).

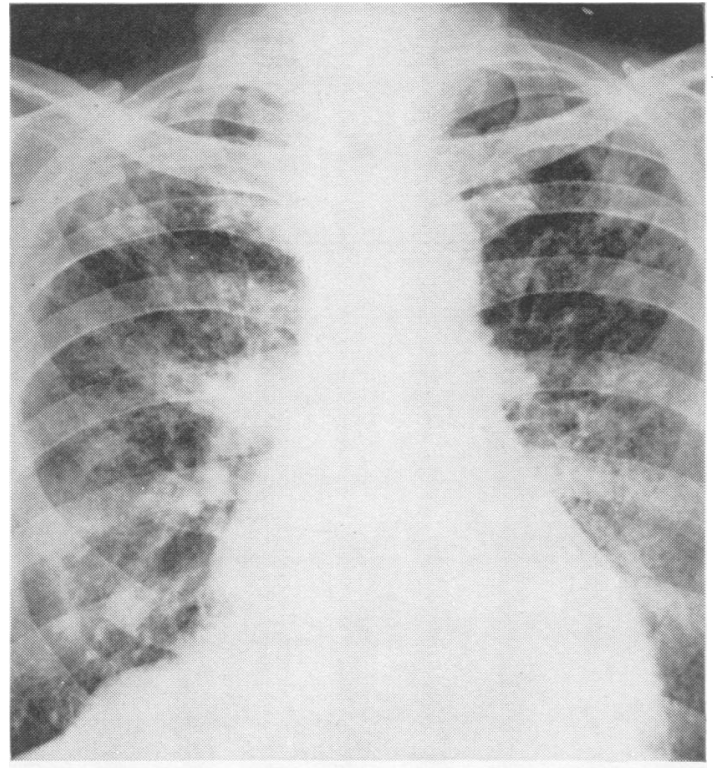

FIG. 6.-Radiograph of Case 5 (A. L.).

Case 4.-A man (N. C.) aged 39 was first seen in June, 1952 , in the course of contact investigation of a case of tuberculosis in his household. He was, and still remains, entirely free from symptoms. He had had pneumonia in infancy; there was no relevant family history save as above.

He left school aged 15, worked in agriculture for four years, as a baker for four years, as a boat-hand two years, as a kettle-boy in clay works two years. He was in the Royal Navy for six years, followed by 14 years at the clay works, mainly engaged in shovelling bulked dried clay into bags, which he stated was a dusty job.

He was a healthy and well-built man, and showed no abnormal clinical physical signs. The radiograph showed uniform fine miliary mottling throughout both lung fields, with well-marked calcification at the left hilum. The sputum was persistently negative for tubercle bacilli. The skin tuberculin test was positive.

Follow-up over the succeeding two years has shown no progression in the radiological appearances, which are unchanged, and this has been considered sufficient to exclude any infective cause for the radiological appearances.

Case 5.-A man (A. L.) aged 73 was first seen in November, 1954, complaining of an attack of right axillary pain, of pleuritic type, and a single small haemoptysis. He had some cough and scanty white sputum, and physical signs of emphysema only. He denied habitual cough, and stated that normally he has no more shortness of breath than could be expected at his age. The cough and pain disappeared in a few weeks and there was no further haemoptysis. There were no definite signs or symptoms of cardiovascular origin. 
He now has no cough, no pain, no shortness of breath beyond the average for his age, and no cardiac symptoms.

He worked at open limestone quarries for 12 years, then for 20 years bagging milled china-clay by hand, filling brown paper bags with a hand shovel, in a chamber through whose ceiling the milled product was discharged from a mill on the floor above. (This was a far more dusty occupation than any likely to be encountered under present-day working conditions.) He was subsequently foreman in charge of loading china-clay into trucks (moderate or negligible dust exposure) until retirement two years previously. His retirement was due to his age and anxiety about his health following the so-called heart attack four years previously rather than to respiratory disability.

Physical examination showed him to be normal or better than average for a man aged 73 .

The radiograph (Fig. 6) showed generalized small discrete nodular mottling, with increase of the root shadows and of the lung markings; there was some coalescence of the opacities in the upper zones, but no definite massive fibrosis.

Case 6.-A man (L. M.) aged 64 was first seen in April, 1954, complaining of cough and shortness of breath. He was able to walk any distance on level ground but was handicapped uphill. The cough had been worse during the previous 12 months, but he had had it for years. Sputum was white, scant, never bloody. There was no relevant history of past illness nor any family history of any respiratory disease.

He worked for 43 years in the docks, loading cargo in the holds of small vessels. Most of the time was spent loading china clay, and it is a very dusty job. He had, however, loaded or unloaded cargoes of coal from time to time also, and in his early life worked for three years as a timberman in a coal-mine in South Wales. He never worked at the coal-face. He estimated the amount of coal working he had done at less than a

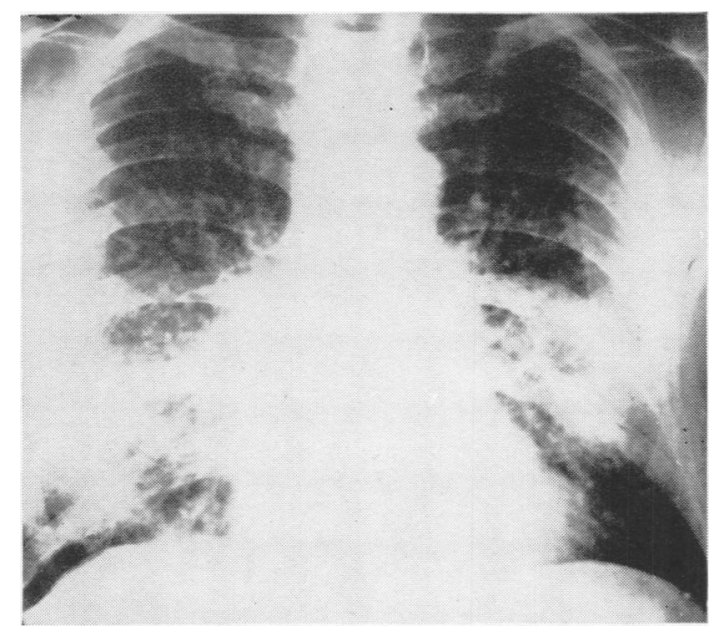

FIG. 7.-Radiograph of Case 6 (L. M.). quarter of his work. (Enquiry at the docks showed that about three or four cargoes of coal had been handled annually, and $\mathbf{2 0}$ or more of clay weekly.)

He was a healthy-looking man with no anaemia or cardiovascular cause for his breathlessness. Clinically, there was probably some emphysema, and fine rales were audible at both bases. The radiological appearances (Fig. 7) showed considerable accentuation of the bronchovascular markings in the lung fields and definite nodular mottling. His corrected vital capacity was 2 litres.

This case illustrates the difficulty in Cornwall of finding a completely " pure" history of exposure to china-clay dust alone. We have seen two or three other cases in which similar or more marked radiological appearances (and clinical disability also) were present, and the history was preponderantly of exposure to china-clay, but also included a year in tin-mining, a year gold-mining in the U.S.A., or the like. Details of these cases are not quoted, for it is felt that these other exposures detract from their interest.

\section{Lung Dust Analyses}

In Case 1 (C. P.) the dried right lung weighed ca $115 \mathrm{~g}$. A representative sample of powdered lung tissue was ashed at $380^{\circ} \mathrm{C}$ and the ash extracted with cold $2 \mathrm{~N} \mathrm{HCl}$. The lung dust produced in this way was $8.2 \%$ of the dried lung, corresponding to perhaps $18 \mathrm{~g}$. of dust in both lungs.

Radiological diffraction diagrams of kaolin from Cornwall and of the lung dust are shown in Figs. 8a and $8 \mathrm{~b}$. They indicate much kaolin, little mica, and $1 \%$ or less of quartz; electron micrographs (Fig. 9) show the material to be similar to commercial china clay from Cornwall, although there were areas seen in the photograph where the material appeared to be attacked or altered.

Partial chemical analyses of the lung dust and of a sample of kaolin from Cornwall gave:

\begin{tabular}{|c|c|c|}
\hline & Lung Dust & Kaolin \\
\hline 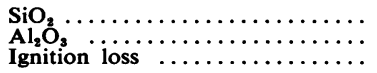 & $\begin{array}{l}52 \% \\
30 \% \\
15 \%\end{array}$ & $\begin{array}{l}46.5 \% \\
39.6 \% \\
13.9 \%\end{array}$ \\
\hline
\end{tabular}

These figures show an excess of silica, which was certainly not present in the form of quartz. A quantitative mineral determination by an internal standard radiological diffraction technique (Griffin, 1954) showed $50 \%$ of kaolin and 10 to $20 \%$ of mica. This is in agreement with the chemical results, except for an excess of $\mathrm{SiO}_{2}$ of the order of 15 to $20 \%$ of the sample.

Amorphous silica is much more easily soluble in dilute alkali than the silica of most silicate minerals or quartz. Repeated extractions with hot $5 \% \mathrm{NaOH}$ 


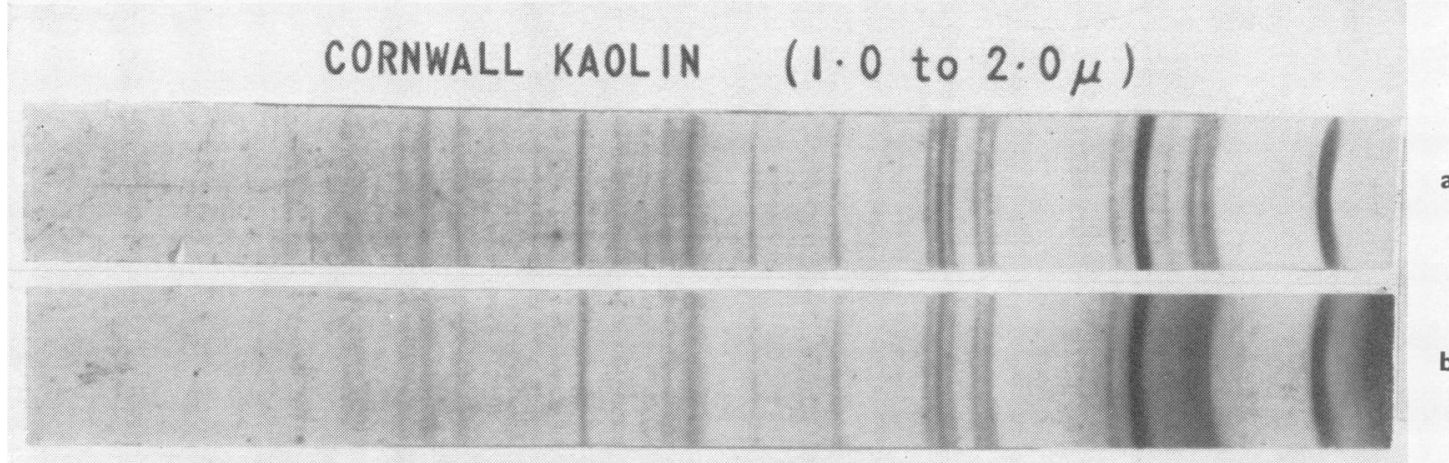

\section{GEORGIA KAOLIN $(0.5$ to $1.0 \mu)$}

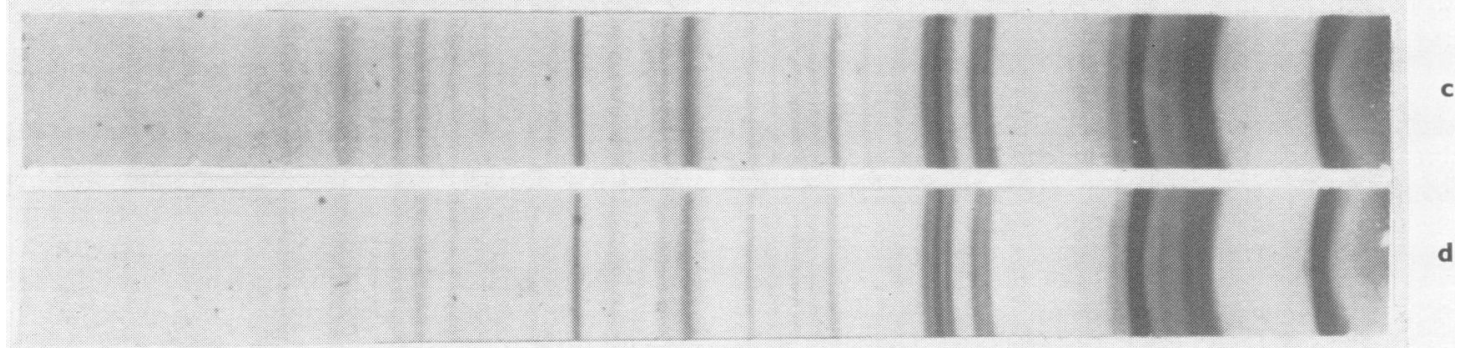

\section{AMERICAN LUNG RESIDUE}

FIG. 8.--Radiological diffraction diagrams:-

(a) Kaolin from Cornwall.

(b) Lung residue of Case 1 (C. P.).

for half a minute were therefore made of the lung residue and of a kaolinite sample of similar size, 1 to 2 microns, and the $\mathrm{SiO}_{2}$ in solution was determined colorimetrically.

The results are shown in Table 1.

TABLE 1

SILICA DISSOLVED FROM LUNG DUST AND FROM KAOLIN BY $\mathrm{NaOH}$

\begin{tabular}{c|c|c}
\hline $\begin{array}{c}\text { No. of } \\
\text { Extraction }\end{array}$ & $\begin{array}{c}\text { Percentage } \\
\text { Lung Residue }\end{array}$ & $\begin{array}{c}\text { Percentage } \\
\text { Kaolin }\end{array}$ \\
\cline { 3 - 3 } 1 & 14.6 & 0.33 \\
2 & $1 \cdot 3$ & 0.3 \\
3 & 0.45 & 0.03 \\
4 & 0.51 & - \\
5 & 0.36 & - \\
\hline
\end{tabular}

It appears from these tests that $15 \%$ of the isolated lung dust was present as amorphous silica, the remainder being mainly kaolinite and some mica. There are two possible explanations for the presence of amorphous silica: (1) That the man was exposed to sodium silicate dust which is used to deflocculate clay suspensions. The amorphous silica may be the residue of the sodium silicate. However, sodium silicate forms only a very small percentage of the clay and there is said to be no dust hazard from it. (2) That the kaolin may have been attacked in the lung and a certain amount of alumina removed, leaving a corresponding amount of amorphous silica with the remaining kaolin. Treatment with cold $2 \mathrm{~N}$ hydrochloric or sulphuric acid does not attack kaolin, and it requires hot concentrated sulphuric acid to remove appreciable amounts of alumina. It will be seen that neither explanation appears satisfactory.

Case 7.-Through the courtesy of Dr. R. W. Edenfield we received for analysis a sample of fibrosed lung tissue of a (Negro) kaolin worker (W. M.) from Georgia, U.S.A., with some notes, from which the following are excerpts:

W. M., who died aged 44, in 1953, worked for over 20 years as a labourer in a kaolin plant and had never been employed elsewhere. He had worked for several 


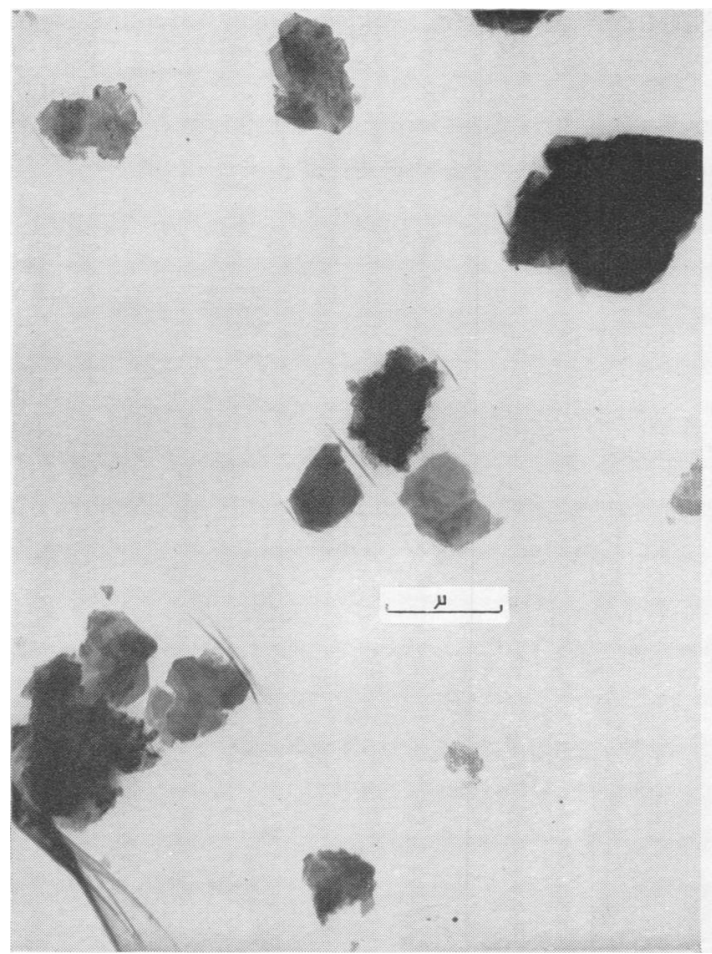

FIG. 9.-Electron micrographs of lung residue from Case 1 (C. P.).

years in the bagging and loading area, which is rather dusty. In 1946, a radiograph showed " moderately advanced pneumoconiosis " and in 1948 he complained of shortness of breath. A radiograph taken a few days before death is shown in Fig. 10. W.M. died in 1953

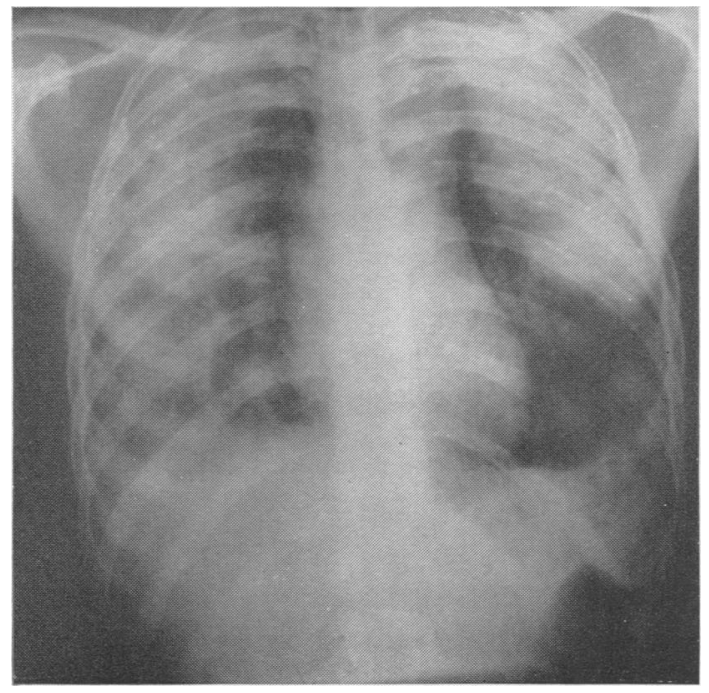

Fig. 10.-Radiograph of Case 7 (W. M.). and the following is an excerpt from the necropsy report:

"The lungs are converted into stony hard masses. Less than a quarter of the lung volume is crepitant. The remainder is cartilage-hard and fibrous and cuts with a gritty sound. There is a pneumonic consolidation within parts of the right lower lobe. There is considerable pleural thickening about the apices on both sides."

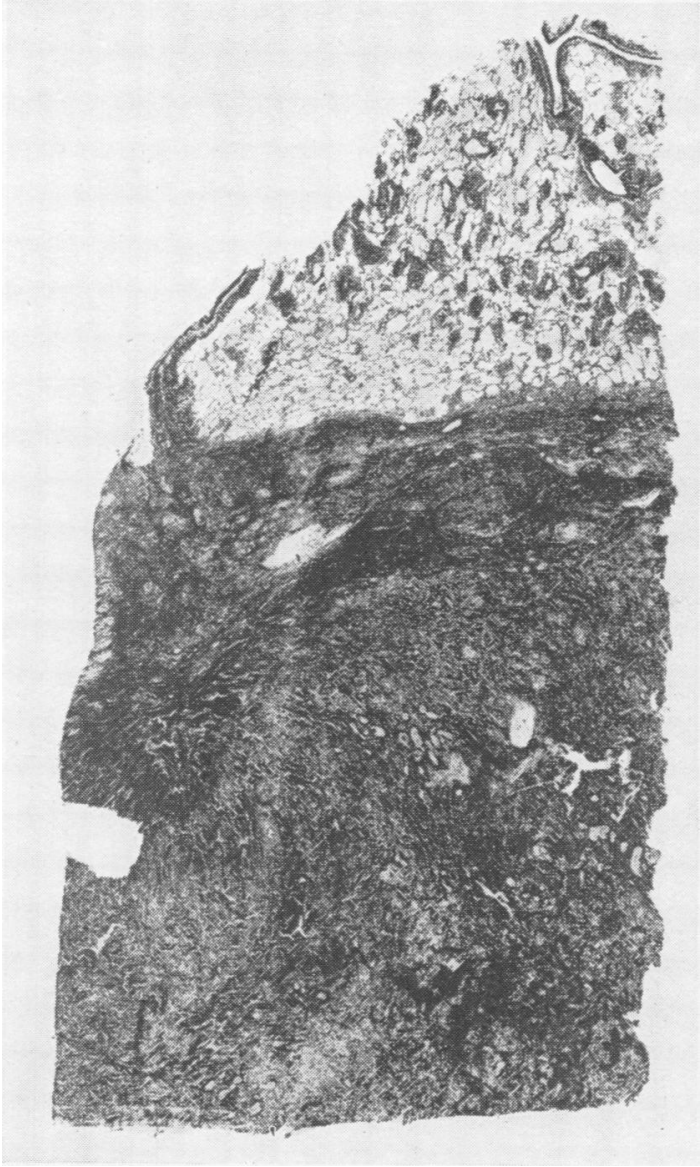

FIG. 11.-Section of fibrosed area with adjacent area of nearly normal lung. Haematoxylin and eosin $\times 25$ (Case 7, W. M.).

Histological examination of a fibrosed part of lung tissue (Fig. 11 and 12) was done by Professor C. V. Harrison, of the Postgraduate Medical School of London, who commented as follows:

"The specimen consists of a part of a nodule together with a fringe of surrounding lung. The nodule is grey with a paler edge and it is not nearly as hard as a silicotic or fibrotic nodule.

The nodule consists of a rather loose framework of reticulin and collagen in which are embedded masses 


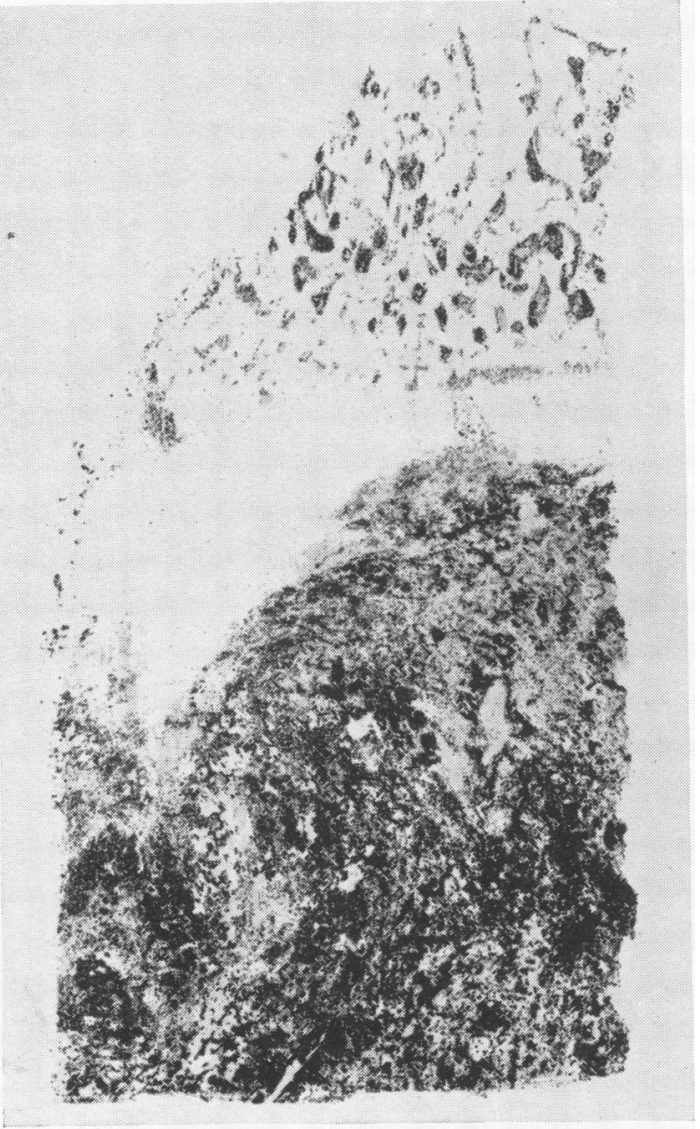

Fig. 12.-Microincinerated serial section of Fig. 11 .

of kaolin. The whole nodule appears to be necrotic and its vessels are all obliterated by endangeitis. No acid-fast bacilli were seen but the nodule contains a fungal mycelium.

This is a remarkable lesion. It is quite unlike a silicotic lesion but it does bear a strong structural resemblance to the massive lesions of South Wales coal-miners."

Some of the fibrosed tissue was ashed at $380^{\circ} \mathrm{C}$ and the ash extracted with $2 \mathrm{~N} \mathrm{HCl}$. The residue obtained was 35 to $40 \%$ of the oven-dried lung, an unusually high value.

Partial chemical analysis of the residue gave:

\begin{tabular}{l|c|c}
\hline & $\begin{array}{c}\text { Percentage } \\
\text { Residue }\end{array}$ & $\begin{array}{c}\text { Percentage } \\
\text { Kaolin (theoretical) }\end{array}$ \\
\hline $\mathrm{SiO}_{2}$ & $46 \cdot 5$ & $46 \cdot 5$ \\
$\mathrm{Al}_{2} \mathrm{O}_{3}$ & 40 & $39 \cdot 6$ \\
$\mathrm{Ignition} \mathrm{loss}$ & 12 & $13 \cdot 9$ \\
\hline
\end{tabular}

Radiological diffraction analysis showed a strong kaolinite and a very weak anatase $\left(\mathrm{TiO}_{2}\right)$ pattern.
No trace of quartz could be seen. Quantitative determination by radiological diffraction gave $98 \%$ kaolinite. Radiological diagrams of the lung dust and of kaolin from Georgia of similar size are shown in Fig. 8, and an electron micrograph of the lung dust in Fig. 13.

The residue appears to consist entirely of kaolinite.

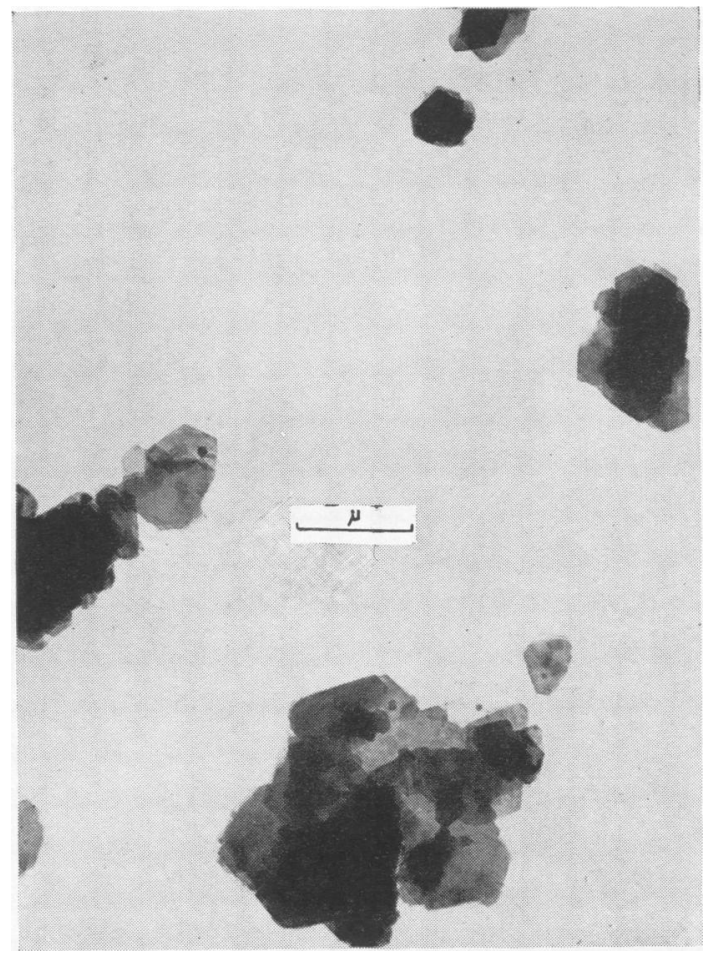

Fig. 13.-Electron micrograph of lung residue from Case 7 (W. M.).

\section{Discussion}

The possibility that kaolin could present a pneumoconiosis risk has been discussed for many years. Animal experiments (Policard and Collet, 1954; Rüttner, Bovet, Weber, and Willy, 1952; King, Harrison, and Nagelschmidt, 1948) have shown kaolin to be intermediate between an entirely inert dust such as coal and a fibrogenic dust such as quartz. An enhancement of kaolin fibrosis by dead tuberculosis bacilli has also been reported (Kettle, 1934): this finding has recently been confirmed by Attygalle, Harrison, King, and Mohanty (1955).

Cases of radiological abnormalities and shortness of breath together with an exposure history to kaolin dust in the absence of quartz have been reported by Bastenier (1950), Cavigneaux, Charles, 
Fuchs, and Tara (1950). Lynch and McIver (1954) described two cases of pulmonary fibrosis from kaolin workers in South Carolina and gave the name kaolinosis to this condition.

Our clinical, radiological, and pathological observations and the two dust analyses which show comparatively large amounts of kaolin and an almost complete absence of quartz confirm that kaolin dust can cause disabling pneumoconiosis and death. In Cornwall most of the processes in kaolin production are wet and there is no dust risk except in drying, disintegrating, and bagging of fine clays. Only a small proportion of the labour force is likely to be at risk. Dry disintegration and loading of clay rocks such as are used in some other production centres might present a higher dust risk.

The type of fibrosis produced was, in Case 7 (W. M.), similar to the massive fibrosis seen in coal and haematite miners; and the radiological appearances in Case 2 (W. K.) were of this type. In Case 1 (C. P.) the fibrosis was more of the nodular hyaline type, but the lack of characteristic fibrosis in the hilar glands is a difference from that usual in silicosis.

In Case 7, there was no macro- or microscopic evidence of tuberculosis at death, nor any history of tuberculosis during adult life. In Case 1 (C. P.) there was frank tuberculosis, but it could not be decided how late during or after the dust exposure the infection had been acquired. It is therefore not possible, on the basis of this evidence, to pronounce upon the aetiological importance of tubercular infection in the production of massive fibrosis in kaolin pneumoconiosis.
Summary

Clinical and radiological observations on workers exposed to kaolin dust show that radiological abnormalities with or without marked disability occur; details of six cases are given.

Post-mortem findings show in one case large amounts of pure kaolinite dust associated with massive fibrosis, but no evidence of tuberculosis, and in the other large amounts of kaolin dust and excess amorphous silica with a more nodular type of fibrosis and progressive tuberculosis.

The amounts of kaolin found in the lungs are of the order of 20 to $40 \mathrm{~g}$. in both lungs. In respect of this large amount of dust, the condition is similar to the pneumoconiosis of coalworkers and different from classical silicosis.

We are indebted to Dr. Gwynne Jenkins and Dr. J. C. Mellor for providing us with radiographs and details of two cases, and Professor C. V. Harrison for his report on the histology of one of the cases.

The paper is published by permission of the Ministry of Fuel and Power.

\section{REFERENCES}

Attygalle, D., Harrison, C. V., King, E. J., and Mohanty, C. P. (1955). In the press.

Bastenier, H. (1950). Arch. belges. Méd. soc. 8, 81

Cavigneaux, A., Charles, A., Fuchs, S., and Tara, S. (1950). Arch.

Mal. prof., 11, 34. Safety in Mines Research Establishment, Res. Rep. No. 101.

Kettle, E. H. (1934). J. Path. Bact., 38, 201.

King, E. J.; Harrison, C. V., and Nagelschmidt, G. (1948). Ibid., $60,435$.

Lynch, K. M., and McIver, F. A. (1954). Amer. J. Path., 30, 111. Policard, A., and Collet, A. (1954). Schweiz. Z. allg. Path. Bakt., 17,320 .

Rüttner, J. R., Bovet, P., Weber, R., and Willy, W. (1952). Naturwissenschaften, 39, 332 . 